\title{
Implikasi Tafsiran Muhammad Asad bagi Perkataan 'Islam' terhadap Pegangan Ahl al-Sunnah wa al-Jamaah
}

\author{
Implication of Muhammad Asad's Interpretation of 'Islam' on \\ Ahl al-Sunnah wa al-Jamaah's Belief
}

\author{
NURHAYATI ABDULLAH* \& KAMARUDIN SALLEH ${ }^{1}$
}

\begin{abstract}
Islam is the name of religion promulgated by the Prophet Muhammad (pbuh). Islam has its own specific shariah that distinguishes it from other religions. Based on Quranic reference, the scholars have understood that the only religion that is true and acceptable by Allah is Islam. With regard to Muhammad Asad nonetheless, he has interpreted 'Islam' differently from the interpretation of mu'tabar. Muhammad Asad interpreted 'Islam' as a self-surrender to God with generic language meaning. This study attempts to see the premise of his interpretation which differs from the interpretation of mainstream Muslims. This paper also seeks to investigate the implication of such interpretation to the belief of Ahl al-Sunnah wa al-Jamaah. This study using content analysis method thematically on his work of tafseer, "The Message of the Quran" by selecting texts from the Quran that contain the word 'Islam' and semantically towards some conceptual texts that are related to it and relevant to the religious pluralism issue. The study finds that Muhammad Asad's interpretation in line with liberal approach and contradicts the Ahl al-Sunnah wa al-Jamaah's tenets by accepting and recognizing the truth of other religions that end with inclusivism and religious pluralism.
\end{abstract}

Keywords: Muhammad Asad, Islam, Religious Pluralism, Inclusivism, Liberal Muslim

Perkataan Islam di sisi ulama Ahl a-Sunnah wa al-Jamaah, sudah jelas merujuk kepada nama satu agama yang disyariatkan kepada Nabi Muhammad SAW berdasarkan nas-nas yang terang seperti firman Allah SWT: "Sesungguhnya agama (yang benar dan diredai) di sisi Allah ialah Islam. Dan orang-orang (Yahudi dan Nasara) yang diberikan kitab itu tidak berselisih (mengenai agama Islam dan enggan menerimanya) melainkan setelah sampai kepada mereka pengetahuan yang sah tentang kebenarannya; (perselisihan itu pula) semata-mata kerana hasad dengki yang dalam kalangan mereka. Dan (ingatlah), siapa yang kufur ingkar akan ayat-ayat keterangan Allah, maka Allah amat segera hitungan hisabnya”(Al-Quran, Ali 'Imran 3: 19). [Semua terjemahan ayat AlQuran selepas ini adalah berdasarkan Tafsir Pimpinan Al-Rahman Kepada Pengertian Al-Quran 1998]. Dalam nas yang lain, Allah SWT berfirman: "Pada hari ini, aku telah sempurnakan bagi kamu agama kamu, dan aku telah reda akan Islam itu menjadi agama untuk kamu”(Al-Quran, AlMa'idah, 5: 3). Kedua-dua nas ini merujuk kepada nama satu agama formal yang dibawa oleh Nabi Muhammad SAW.

\footnotetext{
1 Nurhayati Abdullah*(corresponding author), Islamic Affairs Officer at Department of Islamic Development Malaysia (JAKIM), Blok A and B, Kompleks Islam Putrajaya, Presint 3, 62100 PUTRAJAYA, Malaysia, email: nursodiq99@hotmail.com; Kamarudin Salleh, Ph.D., assoc. prof. at Centre for Akidah and Global Peace, Faculty of Islamic Studies, Universiti Kebangsaan Malaysia, 43600 BANGI, Selangor, Malaysia, email: dins@ukm.edu.my.
} 
Pentafsiran perkataan 'Islam' dengan makna yang lain, sudah tentu memberi implikasi berbeza berdasarkan kefahaman terhadap nas-nas di atas yang mengandungi konsep agama dan persoalan akidah kerana ia menegaskan Islam sebagai satu-satunya agama yang diterima di sisi Tuhan. Selain daripada tafsiran muktabar yang merujuk kepada nama agama Islam, terdapat tafsiran lain yang diberikan oleh golongan orientalis dan kelompok muslim liberal yang mengatakan bahawa Islam bukan merujuk kepada satu nama agama yang formal dan bersistem, tetapi hanya sikap berserah diri, tunduk dan patuh kepada Tuhan. Muhammad Syahrur (2002), seorang pemikir liberal daripada Syria sebagai contoh, mengatakan, "Islam dan iman merupakan dua hal yang berbeda (berbeza). Islam lebih dahulu dari iman. Dan muslimin tidak terbatas mereka pengikut Muhammad".

Muhammad Asad juga mentafsirkan Islam sebagai penyerahan diri kepada tuhan (self surrender to God) mengikut makna bahasa secara generik (umum, tidak khusus), bukan merujuk kepada nama sebuah agama yang formal. Percanggahan ini dianggap oleh Muhammad Asad sekadar perbezaan pandangan yang lazim berlaku sebagaimana para ulama terdahulu jua berselisih pendapat sesama mereka. Perbezaan pendapat menurut beliau adalah asas kepada kemajuan pemikiran manusia dan pendorong terkuat dalam penerokaan ilmu (Muhammad Asad 1980: viii). Isu tafsiran perkataan al-Islam yang dibangkitkan oleh Muhammad Asad adalah penting untuk dibincangkan. Ini kerana perbezaan di kalangan ulama muktabar walaupun berlaku pada perkara ijtihad, mereka masih sepakat dalam perkara Usul. Perbezaan mereka masih berada dalam kerangka tauhid. Oleh itu kajian ini akan melihat premis pemikiran beliau dan sejauh mana tafsiran Muhammad Asad mengikuti kerangka tauhid sehingga dapat dinilai sama ada perbezaan pandangan beliau boleh dianggap lazim di sisi syarak atau sebenarnya menyalahi syarak berdasarkan implikasi pentafsiran perkataan Islam menurut perspektif beliau tersebut.

\section{Latar Belakang Muhammad Asad}

Beliau adalah pengarang terjemahan beserta huraian al-Quran berbahasa Inggeris, The Message of the Quran. Turut dikenali sebagai pemikir Islam kerana menulis beberapa karya lain mengenai politik Islam dan umat Islam antaranya Islam at the crossroad" dan This Laws of Ours and Other Essays. Dilahirkan pada 2 Julai 1900 di bandar Lviv (sekarang di negara Ukraine yang terletak di Timur Galicea, yang dahulunya merupakan sebahagian daripada empayar Austro-Hungarian) dan meninggal pada tahun 1992 di Malaga, Sepanyol (Muhammad Asad 2016: xi). Beliau berketurunan Yahudi yang berlatar belakang pengaruh Rabbi yang kuat daripada susur galur kedua-dua orang tuanya dan memeluk Islam pada tahun 1926. Nama asal beliau sebelum memeluk Islam ialah Leopold Weiss. Sejak kecil beliau telah mempelajari kitab-kitab suci Yahudi - Kristian, Old Testamen dan mendalami teks Talmud, Mishna, Gemarra dan Targum dengan bahasa Ibrani (Hebrew). Beliau turut menguasai bahasa Aramaic, Poland dan Jerman (Muhammad Asad 1981, 2016: xi). Dia tidak menghabiskan pengajiannya dalam bidang falsafah dan sejarah seni di Universiti Vienna, tetapi meninggalkan pengajiannya untuk berhijrah ke Berlin demi menceburi bidang kewartawanan. Profesion tersebut membawanya merentasi negara Arab dan mengenali dunia Islam seperti Mesir, Maghribi, Arab Saudi, Iran, Afghanistan, Syria, Amman, Iraq, Kurdistan, Asia Tengah dan Selatan Russia.

Nama beliau mendapat perhatian antarabangsa selepas menghasilkan sebuah kisah autobiografi bertajuk The Road to Mecca mengenai persinggahannya di Tanah Arab dan pemelukan agama Islamnya sekitar tahun 1927-1932 (Muzaffar Iqbal 2016: 3). Penghasilan The Message of the Quran dengan pendekatan moden melonjakkan namanya sebagai sarjana Muslim. Walau bagaimanapun, menurut satu kajian, Muhammad Asad mendiamkan atau tidak mendedahkan dengan siapa beliau mempelajari disiplin agama Islam, di mana beliau mendapat pendidikan formal pengajian Islam, apakah bahan bacaan yang menjadi rujukan beliau sepanjang tempoh persinggahan beliau di Tanah Arab, dan apakah yang membentuk pandangan alam 
(worldview) beliau, serta apakah gambaran beliau terhadap tradisi Islam? Kekurangan maklumat-maklumat ini menjadikan hampir mustahil untuk menilai tahap kepakaran, pengetahuan dan kefahamannya mengenai keluasan ilmu al-Quran, hadis, dan fekah (Muzaffar Iqbal 2016: 15-16).

\section{Pendekatan Tafsir Muhammad Asad}

Dalam prakata The Message of the Quran, Muhammad Asad menekankan kepentingan pengetahuan filologikal (ilmu yang mempelajari bahasa dalam sumber-sumber sejarah yang ditulis, yang merupakan kombinasi daripada kritik sejarah, sastera dan linguistik) dalam penterjemahan dan pentafsiran al-Quran. Muhammad Asad berpandangan bahawa al-Quran tidak dapat difahami dengan tepat sekiranya dibaca dengan mengambil kefahaman Islam yang telah mengalami perkembangan tamadun sebagaimana ramai memahaminya hari ini kerana masyarakat Arab pra Islam ketika itu tidak memahami agama sebagai sistem lengkap yang diinstitusikan (institutionalized) dengan set undang-undang, prinsip dan amalannya seperti hari ini. Menurut beliau pemahaman terhadap al-Quran tidak mencapai maksud sebenar dan kehilangan rupa asal kerana umat hari ini hanya mengetahui Islam yang "diinstitusikan" setelah melalui proses sejarah dan pembangunan ideologi. Beliau memberi contoh berkenaan tafsiran perkataan 'Islam', kebanyakan orang termasuk para sarjana Arab hari ini menganggap Islam dan Muslim adalah eksklusif merujuk kepada pengikut Nabi Muhammad tanpa menyedari pengertiannya yang lebih luas. Pandangan ini sama seperti pendapat Wilfred Cantwell Smith (1916-2000), seorang ahli teologi Kristian Liberal yang mengatakan bahawa Islam pada asalnya bukanlah suatu sistem kepercayaan yang lengkap tetapi hanya berkembang kemudian menjadi suatu tradisi (agama) yang tersendiri pada abad ke-19 apabila orang Islam menulis buku-buku yang meletakkan Islam sebagai agama formal (institutionalized religion) (Khalif Muammar 2013:13). Oleh itu bagi Smith juga, perkataan Islam dalam al-Quran merujuk kepada makna literal yang bermaksud berserah diri kepada Tuhan dan bukan nama khas bagi satu agama yang mempunyai suatu sistem kepercayaan.

Kenyataan Muhammad Asad juga seakan-akan pendekatan hermeneutik al-Quran yang diperkenalkan oleh Muhammad Arkoun, seorang pemikir muslim kontemporari dari Algeria yang turut memperkenalkan Applied Islamology dalam model Pengajian Islam berdasarkan model orientalis yang mengkritik pengajian tradisional. Beliau mengkritik model Pengajian Islam yang terlalu turath centris dan logo centri" (dalam tradisi Sains dan Falsafah Barat merujuk kepada perkataan dan bahasa sebagai ekspresi asas terhadap realiti luaran) yang dianggap menyebabkan kemunduran keilmuan Islam. Secara umum, model beliau mengkaji Islam dalam kerangka paradigma humanisme ke atas semua subjek dalam Pengajian Islam (Tafsir, Fekah, Tasawwuf, Kalam dan lain-lain) sehingga menembusi aspek teologi dan Usuliyyah (Kholili Hasib 2014: 310311). Arkoun mendefinisikan hermeneutik sebagai usaha untuk mentafsirkan Kitab suci dari sudut sejarah, sosiologi dan antropologi dengan menolak segala bentuk pentafsiran para teologis dan tradisionalis yang pada pandangan beliau, cara berfikir mereka dianggap suci oleh umat Islam (Khalif Muammar 2009).

Nadzrah dan Ahmad Nabil (2016) berpandangan bahawa Muhammad Asad menggunakan metod hermeneutik al-Quran yang disamakan dengan kaedah al-ta'wil dalam ilmu tafsir. Mereka menyatakan bahawa falsafah hermeneutik, pemikiran kritis dan rasional serta projek pembaharuan tergambar dalam huraian atau tafsiran Muhammad Asad yang dicerminkan daripada projek pembaharuan yang didokong oleh Syeikh Muhammad Abduh dan Sayyid Rasyid Rida di dalam Tafsir al-Manar. Asad sendiri mengakui bahawa beliau banyak mengambil rujukan daripada kedua-dua tokoh tersebut dalam tafsir beliau yang dianggap pemikir moden Islam yang hebat (Muhammad Asad 1980: 14). Hermeneutik merupakan satu disiplin mengenai teori dan praktis untuk memahami dan menginterpretasi (memberi makna) sesuatu teks. Ia telah memberi sumbangan penting kepada dunia Barat kerana sejak berabad-abad lamanya telah digunakan 
dalam pentafsiran dan perdebatan Homerik di zaman Yunani kuno, tafsiran rabbinikal (rabbinical interpretation) terhadap Taurat dan Injil, juga menangani kontroversi teologi semasa zaman reformasi Protestan di Eropah (Prasad 2002: 14). Akhirnya ia menjadi sinonim dengan pentafsiran Bible kerana sejak sekian lama ia sentiasa dikaitkan dengan huraian dan tafsiran Bible. Daripada zaman Grik kuno, ia dibawa ke zaman moden dengan fokus baru terutamanya di Jerman selepas reformasi dengan berlakunya perpindahan tanggungjawab mentafsirkan Bible daripada pihak gereja kepada individu Kristian secara umum (Forster 1996: 1).

Terdapat perbincangan dalam hermeneutik bahawa Bible hendaklah diberi interpretasi sama sahaja sebagaimana teks-teks lain (yang bukan kitab suci) terutama oleh Schleiermacher (dikenali sebagai bapa hermeneutik moden) dan Herder (Forster, 1996:3). Menurut Prasad (2002:14), hermeneutik turut mengalami evolusi sehingga berkembang menjadi berbagai-bagai variasi seperti juridical hermeneutics, philological hermeneutics, philosophy hermeneutics dan seumpamanya. Murid dan pengikut Schleiermacher, August Boeckh, dalam bukunya Encyclopedia and the Methodology of the Philological Science telah menetapkan empat aspek asas dalam proses interpretasi yang perlu diberi penekanan iaitu sejarah, linguistik, individual (disebut sebagai aspek psikologi oleh Schleiermacher dan Herder) dan generik (Forster 1996: 20). Dalam aspek bahasa, pengetahuan linguistik diperlukan untuk menyelesaikan masalah perbezaan bahasa antara terjemahan Bible dalam bahasa Inggeris dengan bahasa kuno yang tidak lagi digunakan pada hari ini untuk menulis Bible seperti bahasa Ibrani kuno dan Yunani Kuno. Menurut Tengku Intan Zarina Tengku Puji dan Muhd Najib Abdul Kadir (2013), hermeneutik digunakan untuk mencari nilai kebenaran Bible dan makna yang dikehendaki pengarangnya kerana terdapat banyak dokumen yang berbeza-beza mengenai Bible. Oleh itu timbul kekeliruan mengenai keaslian Bible dan masalah dalam memahami kandungannya. Bahkan dikatakan terdapat ribuan versi Bible yang berbeza-beza antara satu sama lain.

Fahmi Salim (2010) menyatakan bahawa kaedah dan aturan dalam bidang hermeneutik untuk memahami Bible dalam Peradaban Barat sekular dengan cara menundukkannya dalam ruang sejarah, bahasa dan budaya yang terbatas adalah tidak bertepatan dengan konsep tafsir atau ta'wil dalam khazanah Islam. Tidak dinafikan bahawa konteks kepada nas-nas al-Quran seperti asbab al-nuzul (sebab turun sesuatu ayat) dan budaya keseluruhan ketika nas itu diturunkan perlu diambil kira. Para ahli tafsir terdahulu juga menguasai asbab al-nuzul, al-siyaq (konteks sesuatu ayat) dan al-sibaq (hubungannya dengan ayat-ayat yang sebelumnya) untuk memahami sesuatu nas. Walau bagaimanapun, itu tidak membataskan nas-nas al-Quran kepada masyarakat Arab, lingkungan budayanya dan zaman ia diturunkan semata-mata. Al-Quran sebagai mukjizat Nabi Muhammad SAW sentiasa kekal memberi petunjuk sepanjang masa, melangkau sempadan tempat, budaya, bangsa dan ketamadunan.

Ringkasnya, ilmu bahasa dan pengetahuan sosial antropologi semata-mata tidak mencukupi untuk memahami al-Quran sebagaimana yang dikehendaki maksudnya oleh Allah SWT apatah lagi bahasa al-Quran adalah bahasa Arab yang mempunyai keistimewaan dan ciriciri tersendiri. Oleh itu para mufassirin mempraktikkan metodologi yang ketat dan sistematik dengan merujuk kepada nas-nas al-Quran sendiri juga hadis-hadis Nabi SAW supaya kefahaman mereka tidak terpesong daripada maksud sebenar yang dikehendaki al-Quran. Dengan ini pemahaman mereka tidak menjadi relatif dan subjektif kepada pemikiran sendiri tanpa keterikatan kepada batas-batas akidah dan syariah.

Menurut Syed Muhammad Naquib Al-Attas (2011: 154), peradaban Barat tidak mengenali ilmu Fardu Ain kerana mereka tidak memiliki ilmu yang lain, selain daripada ilmu yang diketahui oleh umat Islam sebagai ilmu Fardu Kifayah. Sedangkan sifat ilmu dan kaedah pendekatan antara ilmu fardu ain dan ilmu fardu kifayah dalam Islam adalah berbeza. Oleh sebab itu pendekatan Barat terhadap ilmu sejak awal kemunculan ilmu sains dan falsafah dalam peradaban mereka hanya berdasarkan pengalaman sejarah intelektual yang mengarah kepada sekularisasi. Pendekatan mereka terhadap kitab suci agama tidak berbeza daripada pendekatan terhadap produk sejarah yang lain dan budaya manusia semata-mata. 
Pendekatan Barat ini turut dicontohi oleh sekelompok muslim terhadap al-Quran dengan bersikap sama seperti peradaban Barat bersikap terhadap kitab suci agama mereka. Al-Attas mengatakan, peniruan pendekatan terhadap kitab suci dalam tamadun lain yang melalui sejarah peradaban berbeza daripada tamadun Islam oleh sekelompok 'Muslim Liberal' mengakibatkan mereka terputus dari pendekatan kognitif dan metodologi terhadap sumber-sumber asli Islam dan Pengajian Islam. Pemisahan hubungan leksikal (makna perkataan di dalam kamus) dan konseptual telah berlaku secara beransur-ansur antara umat Islam dengan sumber Islam dan dengan sumber-sumber islami. Sehingga banyak konsep penting berkaitan Islam menjadi kabur. Pandangan-pandangan asing yang ditimbulkan oleh golongan ini telah mengakibatkan perpecahan dalam kalangan umat Islam, menimbulkan kekeliruan dan memisahkan umat Islam terdahulu dari umat Islam sekarang (Syed Muhammad Naquib Al-Attas 2011: 153-157).

Secara tidak langsung, pandangan al-Attas ini telah memberi petunjuk mengenai perbezaan pendekatan dan pemikiran Muhammad Asad dalam konteks tafsiran dan pemahaman beliau terhadap al-Quran. Al-Attas mengkritik golongan muslim yang meniru cara berfikir dan kepercayaan orang Barat yang menyamaratakan kategori ilmu dalam Islam, iaitu ilmu fardu ain dan ilmu fardu kifayah, terutama di kalangan muslim yang mendapat inspirasi daripada Barat disebabkan oleh ideologi kaum 'pembaharu' modenis. Golongan ini dianggap tidak memiliki prasyarat intelektual, spiritual dan bahasa tentang ilmu dan epistemologi Islam oleh Al-Attas. Mereka bersandarkan semata-mata kepada linguistik dan antropologi sebagai alat metodologi yang diajarkan dalam pelajaran bahasa dan kebudayaan, dan terikut-ikut dengan nilai serta model Barat juga kesarjanaan orientalis dan aplikasi filologi dalam pelajaran kesusasteraan dan sejarah. Oleh itu pendekatan mereka terhadap Al-Quran cenderung kepada tafsiran bebas (liberal) kepada pelbagai tafsiran tanpa batasan yang dibenarkan kerana tidak berlandaskan metodologi mengikut epistemologi Islam.

\section{Tafsiran 'Islam' Perspektif Muhammad Asad}

Muhammad Asad menyatakan bahawa kalimah 'Islam' sepatutnya diterjemahkan sebagai sikap menyerah diri kepada tuhan (self surrender to God) tanpa mengkhususkan terminologi ini kepada sesuatu komuniti atau kumpulan (Muhammad Asad 1980: vi). Dengan kata lain, Islam bukan merujuk kepada nama formal agama yang dibawa oleh Nabi Muhammad SAW dan terminologi Muslim pula bukan merujuk kepada pengikut baginda SAW secara eksklusif. Ketika membuat ulasan berkenaan terjemahan perkataan muslimun dalam Surah al-Qalam (al-Quran 68:35), Muhammad Asad menjelaskan bahawa beliau mengaplikasi makna Islam secara literal berdasarkan konotasi asal perkataan daripada sudut bahasa ke atas semua bentuk kata terbitan dalam al-Quran yang berasal daripada kata kerja aslama- berserah diri. Penterjemahan al-Quran ke atas sebarang kata terbitan daripada kata kerja aslama perlu mengelak daripada memberi pengertian kepada 'agama Islam' dan pengikut Nabi Muhammad SAW kerana menurutnya pemaknaan eksklusif secara formal ke atas agama Islam dan pengikut Nabi Muhammad SAW merujuk kepada tempoh selepas sejarah perkembangan al-Quran, bukan dari awal ketika alQuran diturunkan:

This is the earliest occurence of the term Muslimun (sing. Muslim) in the history of Quranic revelation. Throughout this work, I have translated the terms muslim and islam in accordance with their original connotations, namely, "one who surrenders [or "has surrendered"] himself to God, and "man's self-surrender to God"; the same holds good of all forms of the verb aslama occuring in the Quran. It should be borne in mind that the "intitutionalized" use of these terms -that is, their exclusive application to the followers of the Prophet Muhammad-represents a definitely post-Quranic development and, hence, must be avoided in a translation of the Quran (Muhammad Asad 1980: 885-886). 
Dalam Surah Ali 'Imran, Muhammad Asad menterjemahkan bahawa intipati agama benar yang diterima di sisi Allah adalah sikap berserah diri kepada Tuhan: "Behold, the only [true] religion in the sight of God is [man's] self surrender unto Him; and those who were vouchsafed revelation aforetime took, out of mutual jealousy, to divergent views [on this point] only after knowledge [thereof] had come unto him. But as for him who denies the truth of God's messagesbehold, God is swift in reckoning!' (Al-Quran, Ali 'Imran, 3:19). [Semua terjemahan Bahasa Inggeris selepas ini merujuk kepada tafsiran Muhammad Asad di dalam The Message of The Quran].

Dalam ayat lain surah yang sama, beliau menterjemahkan bahawa Allah tidak akan menerima agama yang selain daripada sikap berserah diri kepada Tuhan: "For, if one goes in search of a religion other than self-surrender unto God, it will never be accepted from him, and in the life to come he shall be among the lost" (Al-Quran, Ali "Imran, 3:85). Beliau juga memberi huraian ayat bahawa sikap menyerah diri kepada Tuhan adalah intipati ajaran dalam semua agama yang benar (Muhammad Asad 1980: 69). Perkataan 'semua' dalam huraiannya (the essence of all true religion), menunjukkan bahawa di sisi Muhammad Asad terdapat agama-agama lain yang benar selain daripada agama Islam.

\section{Implikasi Tafsiran Perkataan “Islam” Perspektif Muhammad Asad}

Sehubungan penjelasan dan kenyataan Muhammad Asad mengenai tafsiran perkataan 'Islam', konsep-konsep penting yang terkandung di dalam makna Islam tersebut telah berubah sehingga berlaku beberapa implikasi ke atas prinsip akidah Ahl a-Sunnah wa al-Jamaah yang membawa kepada isu-isu berikut.

\section{Pluralisme Agama (Kebenaran Semua Agama)}

Seorang tokoh Muslim liberal Indonesia, Nurcholish Madjid telah mengambil rujukan daripada Tafsir Muhammad Asad yang mengatakan bahawa makna Islam dan Muslim dalam al-Quran adalah lebih luas daripada makna istilah itu dalam 'agama Islam', "makna Islam dan Muslim tidaklah terbatas hanya pada suatu kelompok tertentu manusia, tetapi mencakupi setiap sikap "pasrah kepada Allah", dan setiap orang yang menunjukkan sikap demikian"(Nurcholish Madjid 1987: 47). Justeru, beliau berpandangan, oleh kerana Tuhan adalah Maha Esa, kemanusiaan universal adalah satu, maka ajaran tentang kebenaran pun sama (universal). Beliau menyimpulkan bahawa ajaran kebenaran universal tersebut menjadi ajaran dasar Islam yang membawa kepada kebahagiaan dan "keselamatan". Nurcholish meletakkan tiga unsur sebagai dasar agama: percaya kepada Allah, Hari Kemudian dan amal baik dalam hidup sebagaimana terjemahan dan huraian Muhammad Asad terhadap ayat al-Quran dalam Surah al-Baqarah (2:62) yang akan dibincangkan selepas ini dalam konsep keselamatan akhirat.

Sehubungan dengan pemahaman terhadap makna 'Islam' daripada perspektif Muhammad Asad, Nurcholish membuat kenyataan, "Ibarat roda, pusat roda itu adalah Tuhan, dan jari-jari itu adalah jalan dari berbagai (berbagai-bagai) agama. Filsafat (falsafah) perenial juga membagi (membahagi) agama pada level esoterik (batin) dan eksoterik (lahir). Satu agama berbeda (berbeza) dengan agama lain dalam level eksoterik, tetapi relatif sama dalam level esoteriknya. Oleh kerana itu ada istilah ‘satu Tuhan banyak jalan' (Nurcholish Madjid 1999).

Falsafah Perenial yang disebut di atas adalah pemikiran yang didokong oleh golongan perennialist yang percaya bahawa krisis hari ini terjadi ekoran terputusnya peradaban Barat dengan tradisi primordial; iaitu falsafah abadi (sophia perennis) atau agama abadi (religio perennis) yang diperturunkan daripada generasi ke generasi, sepanjang adanya kehidupan manusia (Dinar Dewi Kania 2014: 86-87). Intipati daripada falsafah ini adalah bahawa di dalam setiap agama ada tradisi-tradisi esoterik, ada suatu pengetahuan dan pesan keagamaan yang sama, yang luarannya mempunyai bentuk dan simbol agama yang berbeza. 
Menurut Dinar Dewi Kania (2014: 88) , pengaruh perennialisme di Indonesia bermula apabila terbitnya karya seorang tokoh perenialis, Fritjhof Schuon, The Transcendent Unity of Religion (TUR) pada tahun 1990an dan semakin berkembang melalui pemikiran Seyyed Hossein Nasr. Seyyed Hossein Nasr yang memandang tinggi terhadap Schuon menyimpulkan bahawa falsafah perenial mengandungi pengertian tentang kebenaran yang mengimplikasikan suatu kebenaran batin yang terdapat bentuk-bentuk kesucian yang berbeza dan unik, yang kebenarannya itu adalah satu (Romansah 2017). Konsep TUR atau Konsep Kesatuan AgamaAgama Schuon kemudiannya menjadi landasan sebilangan ahli falsafah untuk melegitimasi fahaman pluralisme agama. Pluralisme agama adalah satu fahaman yang mendakwa kebenaran semua agama sama rata. John Hick, pelopor ideologi pluralisme agama mengatakan bahawa kebenaran mutlak didefinisikan dalam konteks agama atau tradisi tertentu. Hakikat yang mutlak ini boleh difahami dan dirasai melalui pelbagai jalan. Kerana itu setiap agama mempunyai interpretasi yang berbeza tentang Tuhan atau Kebenaran Mutlak. Oleh itu, terdapat lebih dari satu jalan yang membawa manusia kepada Tuhan (Kebenaran Mutlak).

Sehubungan dengan tafsiran Islam perspektif Asad, iaitu 'Islam' sebagai sikap menyerah diri kepada Tuhan sebagai intipati semua agama yang benar memperlihatkan bahawa ber-Islam adalah sesuatu yang sangat semulajadi dan munasabah kerana kepasrahan kepada Tuhan adalah inti makna hidup manusia. Penghayatan seperti ini menurut Nurcholish adalah sikap keagamaan yang benar sepanjang sejarah. Daripada penjelasan ini, dapat dikatakan bahawa mereka yang mengambil rujukan Muhammad Asad dalam konteks interpretasi perkataan Islam, cenderung kepada pluralisme agama. Oleh itu tafsiran Muhammad Asad mempunyai unsur pluralisme agama kerana kebenaran ketuhanan tidak lagi berada pada Islam secara mutlak.

\section{Keselamatan di Akhirat}

Kenyataan Nurcholish mengenai kebenaran semua agama juga bersumberkan rujukan beliau terhadap terjemahan dan huraian Muhammad Asad ke atas ayat 62, Surah al-Baqarah yang memberi fahaman bahawa keselamatan di akhirat tidak dikhaskan kepada mana-mana pengikut agama termasuk Islam: "Verily, those who have attained to faith [in this divine writ], as well as those who follow the Jewish faith, and the Christians, and the Sabians- all who believe in God and Last Day and do righteous deeds- shall have their reward with their Sustainer; and no fear need they have, and neither shall they grieve". Asad menghuraikan bahawa setiap penganut agama sama ada Yahudi, Kristian, Sabi'in dan sesiapa yang mempercayai Tuhan adalah selamat di akhirat asalkan memenuhi tiga elemen prasyarat, iaitu kepercayaan kepada Tuhan, kepercayaan kepada hari akhirat, dan melakukan perbuatan baik di dunia:

The above passage-which recurs in the Quran several times-lays down a fundamental doctrine of Islam. With a breadth of vision unparalleled in any other religious faith, the idea of "salvation" is here made conditional upon three elements only: Belief in God, belief in the Day of Judgement, and righteous action in life. (Muhammad Asad 1980: 14).

Lebih jelas lagi, Muhammad Asad menyatakan bahawa keselamatan di akhirat tidak khusus diperuntukkan kepada mana-mana nama (agama), bahkan ia terbuka kepada sesiapa yang mengakui keesaan Allah dan melakukan perkara-perkara yang baik berdasarkan huraian beliau terhadap ayat al-Quran dalam Surah al-Baqarah (2:112): " Thus, according to the Quran, salvation is not reserved for any particular "denomination", but is open to everyone who conciously realizes the oneness of God, surrenders himself to His will and, by living righteously, gives practical effect to this practical attitude"(Muhammad Asad 1980: 24). Keterangan ini menzahirkan lagi pendirian Muhammad Asad bahawa Islam yang dianuti oleh umat Nabi Muhammad SAW 
bukanlah satu-satunya agama yang benar kerana al-Quran menetapkan hanya tiga syarat yang disebutkan di atas sebagai doktrin asas untuk menjamin keselamatan akhirat.

\section{Peluasan Makna Ahli Kitab}

Pendirian di atas konsisten ketika beliau menjelaskan maksud 'orang-orang yang diberi kitab' dalam Surah Ali 'Imran (3:19) yang dibentangkan di bahagian pendahuluan makalah ini, bahawa ia tidak merujuk kepada Ahli Kitab, iaitu kaum Yahudi dan Nasrani secara khusus sebagaimana kefahaman yang diperturun oleh para ulama mufassirin. Sebaliknya beliau menterjemahkannya sebagai "kaum yang diturunkan wahyu" secara lebih umum. Beliau memberikan kemungkinan bahawa penganut-penganut agama yang mempunyai manuskrip kitab suci yang masih wujud walaupun separuhnya menyeleweng dan telah hilang bahagian yang asal adalah termasuk dalam kategori mereka yang diturunkan kitab (Ahli Kitab).

Most of the classical commentators are of the opinion that the people referred to are the followers of the Bible, or of parts of it- i.e., the Jews and the Christians. It is, however, highly probable that this passage bears a wider import and relates to all communities which base their views on a revealed scripture, extant in a partially corrupted form, with parts of it entirely lost (Muhammad Asad 1980: 69).

Pemahaman Asad diikuti oleh Nurcholish yang menyokong dakwaan Sayyid Muhammad Rasyid Rida yang dipetik daripada Abdul Hamid Hakim, seorang yang dianggap sebagai ulama pembaharu oleh beliau dari Padang Panjang, Sumatera Barat bahawa pengertian Ahli Kitab tidak hanya merujuk kaum Yahudi, Kristian dan Majusi sahaja, tetapi juga termasuk penganut Hindu, Budha, kaum Cina, Jepun dan lain-lain kerana mereka adalah penganut suatu jenis kitab suci yang mengandungi ajaran dasar tauhid atau Ketuhanan Yang Maha Esa sehingga kini.

All these communities at first subscribed to the doctrine of God's oneness and held that man's self-surrender to Him (islām in its original connotation) is the essence of all true religion. Their subsequent divergencies were an outcome of sectarian pride and mutual exclusiveness (Muhammad Asad 1980: 69).

Abdul Hamid Hakim mengatakan memang mereka telah menyimpang daripada tauhid itu, dan terjadi perubahan-perubahan dalam bahagian-bahagian tertentu kitab suci mereka, namun hal itu tidak perlu dihairankan kerana perkara yang sama juga terjadi pada kaum Yahudi dan Kristian (Nurcholish Madjid 1995: 142). Kenyataan ini membawa pemahaman yang sama seperti terjemahan Muhammad Asad ke atas ayat 62 dalam Surah al-Baqarah di atas bahawa kaum Yahudi dan Nasrani akan selamat di akhirat. Terjemahan Muhammad Asad memaksudkan semua kaum Yahudi, Kristian, dan Sabi'in adalah bertauhid kerana mereka telah dianggap beriman kepada Tuhan sekalipun telah menyeleweng daripada tauhid sebagaimana terjemahan dan ulasan beliau mengenai 'orang-orang yang diberikan kitab' dalam ayat 19, Surah Ali 'Imran.

Rujukan ke atas tafsir-tafsir muktabar arus perdana, tafsiran sebenar ayat 19, Surah Ali 'Imran tidak membawa pengertian kepada penerimaan Allah SWT terhadap agama-agama yang lain. Tetapi ayat tersebut menyatakan tentang satu-satunya agama yang benar di sisi Allah adalah agama Islam. Kaum Yahudi dan Nasrani yang mengikuti Nabi-nabi terdahulu juga mengakui kebenaran Islam. Sehinggalah kedatangan Nabi Muhammad SAW sebagai Rasul, tiba-tiba mereka mengingkarinya kerana hasad dengki lalu enggan menerima Rasul daripada kalangan bangsa Arab yang bukan daripada keturunan bangsa mereka. 


\section{Inklusivisme}

Terjemahan dan keterangan-keterangan Muhammad Asad di atas telah meleburkan makna tauhid di sisi Ahl a-Sunnah wa al-Jamaah. Berdasarkan Tafsir Pimpinan Al-Rahman,"beriman kepada Allah" di dalam Surah al-Baqarah (2:62) bermaksud kepercayaan yang disertakan dengan beriman kepada keseluruhan Nabi yang telah diutuskan oleh Allah Taala, mulai dari Adam hingga kepada Nabi Muhammad SAW dan bukan sekadar mempercayai adanya Tuhan yang satu sebagaimana fahaman monoteisme yang kosong daripada ruh tauhid sebagaimana tafsiran Muhammad Asad di atas. Justeru, al-Quran menjelaskan bahawa orang-orang Yahudi, orangorang Nasrani, orang-orang Sabi'in dan sesiapa sahaja yang berada di zaman Nabi Muhammad SAW atau yang datang kemudian daripada itu tidak perlu bimbang dengan keselamatan mereka di akhirat sekiranya mereka beriman kepada Allah Taala (menerima ajaran Islam yang dibawa oleh Rasul terakhir, Nabi Muhammad SAW). Dalam erti kata lain, orang yang tidak beriman kepada Nabi Muhammad dan agama Islam yang dibawanya, maka mereka tetap kafir (Abdullah bin Muhammad Basmeih 1998: 21).

Ibn Al-Anbari mengatakan, seorang muslim itu adalah orang yang mengikhlaskan ibadatnya kepada Allah SWT, iaitu mengikhlaskan agama dan akidahnya kepada Allah SWT; inilah yang tertakhluk pada tafsiran lafaz Islam menurut makna asal bahasa (al-Razi, 2000). Adapun takrifan sudut syarak, Islam adalah keimanan kepada Allah Taala. Maka sekiranya keimanan itu bukan di atas landasan agama Islam, maka ia bukanlah keimanan sebagai agama yang diterima di sisi Allah Taala. Oleh sebab itu, Syed Muhammad Naquib Al-Attas (2013) menyatakan bahawa makhluk pertama yang menunjukkan contoh sikap kafir adalah Iblis walaupun ia mempercayai dan mengakui Tuhan Yang Esa (Allah) sebagai penciptanya. Ia tetap dianggap kafir kerana bersifat sombong, takbur, biadab dalam penyerahannya kepada Tuhan dengan menunjukkan penentangan dan pemberontakan. Sikap Iblis tidak berbeza daripada Yahudi yang enggan menerima Nabi daripada kalangan bangsa lain sehingga menafikan Nabi Muhammad SAW sebagai Rasul terakhir dan berbangga dengan doktrin kemuliaan bangsa mereka sebagai the Choosen People of God.

Penjelasan Muhammad Asad terhadap ayat 19, Surah Ali 'Imran mengenai penyelewengan kaum Yahudi dan Nasrani, tetapi pada masa yang sama beliau mengatakan kedua-dua penganut agama ini bahkan mana-mana kaum yang pernah diberikan kitab adalah selamat di akhirat kerana percaya kepada prinsip oneness of God didapati condong kepada fahaman inklusivisme. Intipati fahaman ini ialah bahawa bukan semua agama sama benar kerana yang paling benar adalah agama yang bertuhankan Tuhan yang benar, agama yang bertuhankan tuhan palsu tetap diterima di sisi Tuhan selagi semuanya mempercayai tuhan walaupun kepada tuhan yang palsu.

Idea Muhammad Asad dilihat turut mempunyai unsur inklusivisme apabila beliau menyebut tentang penyelewengan "orang-orang yang diberikan wahyu terdahulu", tetapi pada masa yang sama mengatakan mereka tetap selamat di akhirat. Menurut Khalif Muammar (2013: 3-7), permulaan idea inklusivisme di kalangan pemikir agama Barat seperti Karl Rahner dan C.S Lewis tercetus dengan memikirkan bagaimana Tuhan Yang Penyayang menetapkan neraka bagi orang-orang yang mati di luar gereja dan tidak pernah mendengar tentang Jesus. Karl Rahner mengatakan bahawa orang-orang dari agama lain akan mendapat keselamatan dengan rahmat Tuhan walaupun kekal dalam agama mereka. Begitu juga dengan C. S Lewis yang berpendapat bahawa setiap doa yang dilakukan dengan tulus ikhlas walaupun terhadap tuhan yang palsu akan diterima oleh Tuhan yang Benar.

\section{Menafikan Pembatalan Syariat Terdahulu}

Terjemahan dan huraian Muhammad Asad seperti yang dibentangkan di atas boleh membawa kepada penolakan terhadap konsep pemansuhan syariat yang terdahulu selepas kedatangan Nabi 
Muhammad SAW. Kenyataan mengenai kebenaran agama lain asalkan mempunyai intipati menyerah diri kepada Tuhan yang tunggal memberi implikasi bahawa syariat terdahulu tidak pernah dibatalkan kerana kaum Yahudi dan Nasrani yang wujud pada hari ini adalah pengikutpengikut para Nabi terdahulu yang menyampaikan ajaran yang benar. Pandangan ini tidak benar kerana para Nabi dan Rasul semuanya menyeru kepada agama hanif, agama yang lurus yang merujuk kepada agama Islam. Agama terbina daripada syariat dan akidah. Syariat, iaitu aspek peraturan, undang-undang dan hukum hakam sememangnya berbeza-beza bersesuaian dengan keperluan zaman atau tuntutan manusia yang sentiasa berubah mengikut waktu para Nabi dan Rasul masing-masing. Oleh sebab itu, syariat yang lama terbatal apabila datangnya syariat yang baru. Kedatangan Nabi Muhammad SAW adalah sebagai penutup keseluruhan Nabi (khatim alNabiyyin) seperti diberitakan dalam Surah al-Ahzab: 40 dan menjadi saksi atas semua ajaran di dunia juga saksi umat ini (Al-Quran, al-Baqarah, 2:143). Setelah Islam sempurna sebagai agama (din) sebagaimana firman Allah dalam ayat 3, Surah al-Ma'idah, maka tiada lagi Nabi dan syariat yang baru selepas Islam.

Menurut al-Tabari (2008), agama hanif yang dibawa oleh para Nabi dan Rasul adalah agama Islam. Dalam ayat 159, Surah al-An'aam, beliau menerangkan bahawa Nabi Muhammad SAW berlepas diri daripada kaum Yahudi dan Nasrani kerana "mereka berpura-pura menjadi pengikut agama yang hanif, kerana membuat perkara-perkara baru dalam agama, yang sesat dari jalan yang lurus dan dari agama yang benar, agama Nabi Ibrahim (millah), iaitu agama Islam". Oleh kerana sikap ingkar kepada ayat-ayat Allah dan sikap kaum Yahudi dan kristian yang enggan mengikut Islam, iaitu satu-satunya agama yang lurus (hanif) yang juga merupakan agama para Nabi dan Rasul, menyebabkan mereka dianggap "orang yang memecahbelahkan agama".

Sekiranya Ahli Kitab (kaum Yahudi dan Nasrani) selepas kedatangan Rasulullah SAW dianggap selamat, diterima di sisi Allah, maka tidak ada keperluan lagi untuk baginda menyeru kepada kalimatun sawa' (kalimah yang sama) sebagaimana diketahui melalui firman Allah SWT: "Katakanlah (wahai Muhammad): "Wahai Ahli Kitab! Marilah kepada satu kalimah yang bersamaan antara kami dengan kamu; iaitu kita tidak menyembah melainkan Allah, dan kita tidak sekutukan denganNya sesuatu jua pun, dan jangan pula sebahagian dari kita mengambil akan sebahagian yang lain, untuk dijadikan orang-orang yang dipuja dan didewa-dewakan selain dari Allah". Kemudian jika mereka berpaling (enggan menerimanya) maka katakanlah kepada mereka: "Saksikanlah kamu bahawa sesungguhnya kami ialah orang-orang Islam"(Al-Quran, Ali 'Imran, 3:64).

Menurut Anis Malik Thoha, (2009: 62), kalimatun sawa' atau kalimat yang sama dalam ayat di atas adalah Islam yang dimaksudkan Allah SWT sebagai agama par excellence iaitu penyelaras antara semua manusia, kerana mereka semua pada suatu ketika pernah menjadi umat seorang Nabi atau Rasul yang diutus oleh Tuhan yang sama. Oleh itu kita diperintahkan mengikuti perintah yang diterima oleh Rasulullah SAW untuk mengajak mereka kepada kalimatun sawa' setiap kali mereka menyeleweng daripadanya, iaitu seruan untuk mentauhidkan Allah, kembali ke pangkal jalan agar mereka mengakui ajaran asal Rasul mereka sendiri sebelum diselewengkan olah para rahib dan pendeta.Daripada huraian kesatuan wahyu samawi ini, Anis Malik Thoha menyimpulkan dengan yakin bahawa agama samawi adalah tunggal. Oleh itu beliau berpendapat bahawa istilah "revealed religions" (agama-agama samawi) yang telah diperkenalkan dengan meluas perlu dinilai semula, melainkan jika ia dimaksudkan kepada 'syariat-syariat' samawi. Anis Malik berhujah bahawa agama para Nabi dan Rasul adalah sama, banyak nas-nas al-Quran yang menunjukkan bahawa mereka menyeru kepada agama hanif, agama yang lurus yang merujuk kepada agama Islam (sebagai contoh rujuk al-Baqarah: 36-137, Yunus: 84, al-Naml: 44, Ali 'Imran: 52, Ali 'Imran: 67). Hanya syariat mereka sahaja yang berbeza-beza dan bersifat tempo-local (spesifik dan relevan dengan masalah dan tuntutan dan ruang waktu masing-masing). Hal ini adalah munasabah dengan keperluan atau tuntutan manusia yang berbeza mengikut perkembangan zaman yang sentiasa berubah. Keterbatasan syariat yang terdahulu, 
menjadikannya sudah tidak sah atau terbatal (mansukh) apabila datang syariat baru yang dibawa oleh Nabi berikutnya.

Kenyataan Anis Malik Toha tidak bertentangan bahkan diperkuatkan dengan apa yang telah dijelaskan oleh Al-Tabari mengenai agama hanif yang dibawa oleh para Nabi dan Rasul di atas yang merujuk kepada agama Islam. Anis Malik memberi contoh Shariah Musawiyyah (kemudian dikenali sebagai Judaisme) dan Shariah Isawiyyah (kemudian dikenali sebagai Kristian) yang masih dipertahankan oleh penganut-penganutnya. Teks-teks suci agama ini mengalami perombakan dan penilaian semula demi penilaian oleh penganut mereka kerana ia sudah tidak relevan dengan semangat zaman. Beliau menyatakan: "Dekonstruksi ini menjadi sebuah kemestian kerana memang sejak mula dalam blueprint ilahi syariat-syariat ini tidak dimaksudkan untuk berlaku universal dan abadi". Berbeza dengan syariat Nabi Muhammad SAW yang memang dimaksudkan sebagai penutup keseluruhan Nabi. Ia telah direkabentuk dengan komprehensif dan fleksibel dengan prinsip ijtihad yang mampu mengakomodasi segala bentuk perubahan dan perkembangan masyarakat moden hingga akhir zaman. Anggapan bahawa Nabi Musa membawa agama Yahudi (Judaisme) dan Nabi Isa membawa agama Kristian adalah tidak berasas kerana dalam kitab-kitab suci mereka, The Bible, tidak terdapat nama atau istilah Judaisme atau Christianity (Anis Malik Thoha 2009: 66).

Implikasi penafian terhadap pembatalan syariat yang terdahulu adalah berlawanan (contradict) dengan terjemahan dan huraian Muhammad Asad ke atas ayat 106 dalam Surah alBaqarah mengenai konsep nasikh mansukh di dalam al-Quran yang ditolak oleh Muhammad Asad (Muhammad Asad 1980:22; Kassis 1985). Menurut beliau, ayat ini harus difahami bersangkutan dengan penggantian Bible dengan al-Quran, bukan bermaksud pemansuhan sebahagian ayat daripada al-Quran sendiri sebagaimana pemahaman para pentafsir terdahulu. Menurut Asad, "doktrin" pemansuhan ayat berlegar di kalangan pentafsir terdahulu berkemungkinan disebabkan kegagalan mereka untuk menyelaraskan antara satu ayat al-Quran dengan ayat lain. Oleh itu, kesukaran tersebut diselesaikan dengan mengisytiharkan ayat yang menjadi persoalan tersebut sebagai ayat mansukh (dibatalkan) (Muhammad Asad 1980: 23).

Dengan mengambil kira pemahaman Asad terhadap agama para Nabi adalah berbezabeza, beberapa konflik persoalan boleh menjejaskan makna Islam perspektif beliau sendiri. Sekiranya Bible telah diganti dengan al-Quran, ia bermakna agama yang membawa ajaran Bible tidak lagi sah. Oleh itu, apakah keperluan atau faedah bagi menggantikan atau tidak antara kitab itu jika Tuhan menerima sama rata sahaja antara agama-agama yang membawa kitab-kitab itu? Secara tidak langsung, ini menunjukkan bahawa kaedah atau pendekatan tafsir yang tidak berpandukan disiplin ilmu tafsir bukan sahaja merosakkan kefahaman Islam yang sebenar bahkan turut membawa masalah kepada tafsiran baru itu sendiri apabila kenyataannya saling bertentangan kerana pemikiran manusia adalah subjektif dan boleh berubah, tetapi ilmu yang datang daripada khabar yang sadiq sentiasa konsisten dan tidak bertentangan bukan sahaja jika dilihat daripada satu sudut bidang ilmu seperti tafsir, tetapi konsisten dengan bidang ilmu fardu ain yang lain seperti tauhid dan usuluddin.

Kesimpulannya, pendekatan Muhammad Asad tidak berbeza daripada premis pemikiran liberal yang berpandangan bahawa sebahagian pentafsiran nas oleh para ulama terdahulu adalah berasaskan kefahaman mereka yang sesuai untuk zaman mereka, tetapi sudah tidak sesuai diterima pada masa kini kerana teks-teks al-Quran sendiri dibatasi oleh sosio-historikal bangsa Arab. Fenomena ini menjelaskan perbezaan yang berlaku dalam mentafsir dan memahami nas alQuran antara tradisi ilmu Islam dan kaedah hermeneutik yang digunakan oleh Muhammad Asad. Akibatnya, muncul idea-idea baru yang diluar kerangka Islam sepertimana implikasi-implikasi yang dibincangkan dalam konteks penterjemahan dan tafsiran Muhammad Asad terhadap perkataan "Islam". Perbezaan pendapat antara Muhammad Asad dan para ulama mufassirin terhadap perkataan "al-Islam" telah melangkau daripada perkara Usul kerana telah meruntuhkan dasar-dasar tauhid apabila beliau merubah konsep-konsep penting yang sepatutnya membezakan antara seorang yang beriman dengan seorang yang kufur. Tafsiran "Islam" 
perspektif Muhammad Asad membawa kepada fahaman pluralisme agama kerana mempunyai unsur kebenaran relatif, iaitu apa pun agama asalkan yang menyerah diri kepada Tuhan adalah benar. Akibatnya, ia memberi pemahaman berikutnya iaitu mana-mana agama yang berserah diri kepada Tuhan ada tempatnya untuk di terima di sisi Tuhan. Hamid Fahmy Zarkasyi (2012) memetik HAMKA sebagai berkata, "orang yang menyatakan bahawa semua agama adalah sama, sebenarnya dia sendiri tidak beragama". Pada masa yang sama, tafsirannya turut mempunyai unsur inklusivisme dalam isu keselamatan akhirat, kerana mendakwa penganut agama lain yang mempunyai kitab akan selamat di samping turut mengakui penyelewengan pengikut ajaran Nabi terdahulu. Kesemua perkara tersebut memberi kesan terhadap prinsip akidah Ahl a-Sunnah wa al-Jamaah kerana dakwaan kebenaran (truth claim) dan keselamatan pada banyak agama adalah bertentangan dengan ajaran tauhid yang terdapat dalam agama hanif iaitu Islam. Oleh itu perbezaan pandangan yang dikemukakan beliau mengenai kelainan tafsiran beliau terhadap perkataan "al-Islam" bukanlah suatu kelaziman yang wajar berlaku sebagaimana perbezaan pendapat dalam perkara ijtihadi yang membabitkan sesetengah hukum Fekah yang tidak qat'ie dalam kalangan para ulama terdahulu.

\section{References}

Al-Quran.

Abdullah bin Muhammad Basmeih. 1998. Tafsir Pimpinan Al-Rahman kepada Pengertian AlQuran. Kuala Lumpur: Dar Al-Fikr.

Anis Malik Thoha. 2009. Fahaman Pluralisme Agama Merosakkan Akidah. Seminar Pemurnian Akidah 2009 (pp. 49-73). Kuala Lumpur: Pejabat Mufti Wilayah Persekutuan.

Fahmi Salim. 2010. Kritik Terhadap Studi Al-Quran Kaum Liberal. Depok: Gema Insani.

Forster, M. N. 1996. Hermeneutics. Cognition (1860), 1-62.

Hamid Fahmy Zarkasyi. 2012. Misykat: Refleksi Tentang Islam, Westernisasi \& Liberalisasi. Jakarta: Institute For The Study Of Islamic Thought And Civilizations (INSISTS).

Dinar Dewi Kania. 2014. Kajian Kritis Pemikiran Epistemologi Frithjof Schuon (1907-1998). Jurnal TSAQAFAH, 10(1), 85-108.

Khalif Muammar. 2013. Islam Dan Pluralisme Agama. Kuala Lumpur: Universiti Teknologi Malaysia.

Kholili Hasib. 2014. Studi Agama Model Islamologi Terapan Mohammed Arkoun. Jurnal TSAQAFAH, 10(2), 309-324.

Muhammad Asad. 1980. The Message Of The Qur'an. Gibraltar: Dar Al-Andalus.

Muhammad Asad. 1981. Islam Di Simpang Jalan. (M. Hashem, ed.). Bandung: Penerbit Pustaka Perpustakaan Salman ITB.

Muhammad Asad. 2016. Islam Di Persimpangan Jalan. (Ahmad Farouk Musa, ed.). Kuala Lumpur: Islamic Renaissance Front.

Muhammad Syahrur. 2002. Islam Dan Iman: Aturan-aturan Pokok. Yogyakarta: Penerbit Jendela.

Muzaffar Iqbal. 2016. The Making Of Free Thinker Of Islam (Part 1): Muhammad Asad. Islamic Sciences, 14(1), 3-24.

Nadzrah Ahmad \& Ahmad Nabil Amir. 2016. Muhammad Asad's the Message of the Quraan. Sociology and Anthropology, 4(12), 1117-1120. doi:10.13189/sa.2016.041211

Nurcholish Madjid. 1987. Islam Kemodernan Dan Keindonesiaan. Bandung: Penerbit Mizan.

Nurcholish Madjid. 1995. Islam Agama Kemanusiaan: Membangun Tradisi Dan Visi Baru Islam Indonesia. Jakarta: Penerbit Paramadina.

Nurcholish Madjid. 1999. Satu Tuhan Banyak Jalan. Bandung: Penerbit Mizan.

Prasad, A. 2002. The contest over meaning: Hermeneutics as an interpretive methodology for understanding texts. Organizational Research Methods, 5(1), 12-33. https://doi.org/10.1177/1094428102005001003. 
al-Razi, Fakhruddin Muhammad Ibnu Umar. 2000. Al-Tafsir al-Kabir Aw Mafatih Al-Ghaib. Vol. 78. Beirut: Dar al-Kutub al-'Ilmiyyah.

Romansah. 2017. Pemikiran Nurcholish Madjid Tentang Filsafat Perenial. Disertasi Sarjana, Universiti Islam Negeri Syarif Hidayatullah.

Syed Muhammad Naquib Al-Attas. 2011. Islam Dan Sekularisme. Bandung: Institut Pemikiran Islam Dan Pembangunan Insan.

Syed Muhammad Naquib Al-Attas. 2013. Islam: The Concept Of Religion And The Foundation Of Ethics And Morality. Kuala Lumpur: IBFIM.

Al-Tabari, Abu Jaafar Muhammad Ibnu Jarir. 2008. Tafsir Al-Tabari. (M. S. Akbar, ed.). trans. Ahmad Affandi et al. Vol. 10. Jakarta: Pustaka Azzam.

Tengku Intan Zarina Tengku Puji \& Muhd. Najib Abdul Kadir. 2013. Kritikan Muslim Liberal terhadap Ulum al-Qur'an: Suatu Kecenderungan Baru dalam Tafsiran al-Qur'an. Islamiyyat. 35(2), 83-88. 